\title{
Ambivalent Blues: \\ Woad and Indigo in Tension in Early Modern Europe
}

\author{
Noor F. K. Iqbal
}

\begin{abstract}
In early modern Europe, blue textile dye was principally obtained from two dye plants, woad and indigo. Of these two dye sources, woad was native in the temperate climes of Europe, while tropical indigo became widely available only after Europe established commercial oceanic trade routes with India and the Americas. Indigo soon became a highly valued import, undermining woad production by unsettling traditional patterns of wealth circulation. Well-established woad producers took powerful steps to protect their industry, but in spite of their efforts, it ultimately succumbed in the face of indigo imports. In this paper, I examine the ways in which the long lasting conflict between the dyestuffs woad and indigo in early modern Europe evokes the tensions between imported and home-grown commodities.
\end{abstract}

In early modern Europe, blue textile dye was principally obtained from two main dye plants, woad (primarily Isatis tinctoria) and indigo (Indigofera tinctoria, among other species). Once blue became a fashionable and significant colour in the late medieval period, demand for blue dye grew exponentially. Of these two dye sources, woad was native in the temperate climes of Europe, while tropical indigo became widely available only after Europe established commercial oceanic trade routes with India and the Americas. Indigo soon became one of the "most valuable of all the "spices," and "undermined the whole European woad industry." Well-established woad producers took powerful steps to protect their industry in the face of "indigo's meteoric rise" in the seventeenth century. ${ }^{2}$ Protectionist measures by dyers' companies and governments included "imperial and local prohibitions" banning the use of indigo on the basis that it was "pernicious, deceitful, eating, and corrosive"-in short, "the devil's dye." 3 However, in spite of the efforts of the woad industry, it ultimately succumbed in the face of indigo imports. In this essay, I will explore the extent of the European woad industry and then examine the ways in which the long lasting conflict between the dyestuffs woad and indigo in early modern Europe evoked the tensions between imported and home-grown commodities.

\section{The Colour Blue}

According to the social historian Michel Pastoureau in Blue: The History of a Color, blue had "little symbolic or aesthetic value" in Europe throughout the high Middle Ages. ${ }^{4} \mathrm{He}$ examines monastic treatises on colour in which blue was conspicuously absent. Common in Europe until the Merovingian period, blue was "effectively banished from the Carolingian

\footnotetext{
1 Jenny Balfour-Paul, Indigo (London: Archetype Publications Ltd.: 2006), 42.

2 Ibid., 39.

3 Ibid., 56.

${ }^{4}$ Michel Pastoureau, Blue: the history of a color (Princeton, NJ: Princeton University Press, 2001), 32.
} 
court" in the ninth century. ${ }^{5}$ Red, black, and white predominated, evoking the blood of Christ, abstinence, and purity respectively, in liturgical colour schemes. ${ }^{6}$ He suggests that blue was slightly more common in artwork and garments, but remained largely devoid of symbolic associations. Woad dye was a staple colourant of pre-Christian Europe, particularly in Celtic and Germanic regions, but was not widely cultivated until blue gained popularity in the twelfth and thirteenth centuries. ${ }^{7}$

Pastoureau argues that blue rapidly rose to "aristocratic and fashionable" heights due to a "complete reorganization of the color hierarchy" in the twelfth century. ${ }^{8}$ Blue became the favoured colour for the Virgin until the eighteenth century, following contemporary iconography based on theological guidelines. ${ }^{9}$ This Marian blue was mirrored by a gradual rise of blue in European heraldry, with up to 30 percent of crests containing the colour by 1400. In literary sources, such as Arthurian and other chivalric legends, the device of a black, red, or white knight was traditionally used to evoke a "predictable response" from the listener or reader, while the blue knight (symbolizing courage and loyalty) only became recognizable by the mid-fourteenth century. ${ }^{10}$ Blue was also chosen as the royal colour of France in the twelfth century as a sign of Marian devotion, contributing to the developing appetite for blue across Europe. ${ }^{11}$ Sumptuary legislation in the late Middle Ages included mandatory "color laws" to indicate categories of "social outcasts" and to mark nonChristians through the use of various combinations of five colours: white, black, red, green, and yellow. ${ }^{12}$ However, blue was one of the few colours "never used as a color of shame or discrimination." 13 Pastoureau postulates that this contributed to the symbolic righteousness accorded to blue. ${ }^{14}$ Since the late medieval period, blue has retained a central role within sumptuary and other chromatic systems. From working class 'blue-collar' clothing to military and naval uniforms, high demand for blue dyes persists into the present.

\section{Woad Production and its Wealth}

It is necessary to understand the extent and deep-rooted nature of the woad industry in order to assess the future tensions between indigo and woad. Changes in woad agriculture and dye methods in the late medieval period allowed the manufacture of bright blues, and the rising demand for blue fueled woad production at an industrial scale. Major treatises on dye and agricultural histories of woad exist in English, German, and French from the eighteenth and nineteenth centuries, providing vital information about the woad industry. Jamieson B. Hurry drew on many such sources in his comprehensive 1930 text The Woad Plant and Its Dye, and offers three chapters detailing the cultivation, manufacture, and dye processes of woad. Leaves of the biannual plant were harvested three to five times during the first year of growth, with each picking containing progressively decreasing

5 Ibid.

${ }^{6}$ Ibid., 37.

7 Jamieson B. Hurry, The Woad Plant and its Dye (London: Oxford University Press, 1930), 51-54.

8 Pastoureau, Blue, 49.

${ }^{9}$ Ibid., 55.

${ }^{10}$ Ibid., 59.

11 Ibid., 60.

12 Ibid., 91-96.

13 Ibid., 96.

14 Ibid., 100 
concentrations of pigment. ${ }^{15}$ Hurry estimates that a bumper crop would produce "three tons" or "five large cart-loads" per acre. ${ }^{16}$ In Britain, wool producers would then run their flocks of sheep over the harvested fields, while the leaves were taken to woad mills for processing. ${ }^{17}$ Three large horse-drawn grind wheels revolved in a "wide circular pan" in which the leaves were reduced to pulp. ${ }^{18}$ The pulp, which was known in France as "pastel or guède," 19 was then drained and rolled by hand into two to six inch balls. The balls were stored in sheds for several weeks until fully dry. ${ }^{20}$ The last stage of dye production involved pulverizing the balls and fermenting or "couching" the resulting powder at a regulated temperature for more than two months, "the whole mass of woad becoming hot and steaming, and emitting disgusting odours." "Finally, it was dried and packed into wooden or wicker barrels and allowed to age for up to four years. The final dye produced was reduced to approximately one-ninth of the original woad that arrived at the mill. ${ }^{22}$

The intensive process of woad production contributed to its high cost, adding to the prestige of the colour blue. Woad has been described as "the universal dye" of late medieval and early modern Europe, as it was not only used to produce blue but also employed in combination with other dyestuffs both as a fixative and to produce a wider range of colours. ${ }^{23}$ Woad mills were established in certain regions of modern-day France and Germany. Although smaller industries existed in England and Italy, a booming export trade carried the dye from entrepott towns in regions like Languedoc and Thuringia, especially to England and northern Italy, which Pastoureau notes, could not produce enough dye to meet the demands of their cloth industries. ${ }^{24}$ As the map reproduced from Hurry in Appendix 1 shows, woad trade was located in textile-manufacturing areas. ${ }^{25}$

Woad became extremely profitable, a veritable "blue gold." 26 The high quality woad of Languedoc in southern France was a prized commodity, with over 100,000 bales exported to the "great woad emporium" of Bordeaux annually, even into the seventeenth century. Hurry estimates that, at the time, a bale would have cost at least $f 15$, leading to a yearly value of some 1.5 million pounds. An anonymous text from as late as 1705 observes regarding Languedoc: "woad... hath made that country the happiest and richest in Europe."27 Traces of this wealth exist in some architectural structures in Europe today. For example, in the south exterior wall of the nave of the Notre-Dame cathedral in Amiens, France, a woad company donated a carving of woad merchants with sacks of woad balls, dating to c. $1300 .^{28}$

\footnotetext{
${ }^{15}$ Hurry notes that English woad generally had three pickings a year, while Languedoc could depend on five harvests a season.

${ }^{16}$ Hurry, The Woad Plant, 16.

${ }^{17}$ Ibid., 11-16.

18 Ibid., 23.

${ }^{19}$ Balfour-Paul, Indigo, 33.

${ }^{20}$ Hurry, The Woad Plant, 21-25.

${ }^{21}$ Ibid., 26.

${ }^{22}$ Ibid., 27. It is interesting to note that across Europe, women participated in the agriculture of woad, but large-scale dye production was a male dominated industry.

${ }^{23}$ F. Lauterbach, Der Kampf des Waides mit dem Indigo (1905), 9. Cited in Hurry, The Woad Plant, 49.

${ }^{24}$ Pastoureau, Blue, 64.

${ }^{25}$ Hurry, The Woad Plant, 182.

26 Pastoureau, Blue, 64.

${ }^{27}$ Balfour-Paul, Indigo, 34.

${ }^{28}$ Hurry, The Woad Plant, Plate XVII, p103; Balfour-Paul, Indigo, 33.
} 
Woad merchants often became wealthy landowners, thereby acquiring significant amounts of power. ${ }^{29}$ Within the credit based economies of Europe, this astronomic wealth offered a source of credit. As historian Margaret Hunt shows for England, few people of the merchant classes had access to secure capital based credit. Instead, creditors relied upon the "presumed strength of kin ties to ensure ultimate payment." 30 In fact, Hunt refers to the image of whole families breaking due to having overextended their credit or "imprudently" provided security as one of the "master narratives of middling culture." ${ }^{31}$ While differences in specificity exist between England and the Continent, it is nonetheless remarkable to read that a Toulouse woad merchant, "the immigrant Castillian Jean de Bernuy," was so "creditworthy that he could even stand as the main guarantor of the sum required for the ransom of King Francis I after his capture by Charles V of Spain" in $1525 .^{32}$ In other reports, woad was so valuable that it was even "bequeathed as property" in wills.

In the German regions of Jülich and Thuringia, Waidstädte or 'woad towns' were the heart of economic activity from the late medieval period onwards. An edict of a count of Holstein in 1236 mentions a tax on woad that was being exported to Flanders via Hamburg. ${ }^{34}$ At the height of production, woad wealth accounted for a "third of the income of Thuringia," and Waidherrn or 'gentlemen of woad' funded construction in places like the medieval city of Erfurt, including its university. ${ }^{35}$ Separate guild fraternities were established to register woad producers and dyers, while town "woad halls" provided warehouse space and quality control. ${ }^{36}$ Heavy woad taxation and restrictions regulated quality, cost, and prices from the thirteenth to the sixteenth centuries and spread woad profits to varying levels of society.

However, not everyone was pleased with the prosperity enjoyed by the woad industry. The rise of the fashionable blue had supplanted the colour red, and "violent conflicts between merchants of madder...and woad" attest to the economic impact of changing colour fashions. ${ }^{37}$ Red and blue dyers, although both "categorized as of the highest order" due to the fastness of their products, ${ }^{38}$ were regulated by separate guilds. (Pastoureau relates that dye guilds were organized based on Aristotelian "chromatic systems" in medieval Europe, in which red, white, and yellow comprise one "sphere," while green, black, and blue comprised its opposite. ${ }^{39}$ ) Madder merchants in Germany attempted to re-signify the colour blue by commissioning stained-glass windows and frescoes featuring blue devils and blue flames of

\footnotetext{
${ }^{29}$ Balfour-Paul, Indigo, 34.

30 Margaret Hunt, The Middling Sort: Commerce, Gender, and the Family in England, 1680-1780 (Berkeley: University of California Press: 1996), 23.

${ }^{31}$ Hunt, The Middling Sort, 34.

32 Balfour-Paul, Indigo, 34; Pastoureau, Blue, 125. Pastoureau cites the merchant's name as "Pierre de Berney."

33 Balfour-Paul, Indigo, 36.

34 Hurry, The Woad Plant, 118.

35 Balfour-Paul, Indigo, 34.

${ }^{36}$ For more detailed information on woad regulations in Germany, see Hurry, The Woad Plant, 122-144. Hurry's laissez faire sentiments emerge in this section, in which he describes "the gross interference with individual liberty and the narrowness of outlook which were characteristic of the period" through "vexatious restrictions" (122).

${ }^{37}$ Pastoureau, Blue, 64.

38 Jenny Balfour-Paul, Indigo in the Arab World (Richmond, Surry: Curzon Press, 1997), 75.

39 Pastoureau, Blue, 74.
} 
hell. ${ }^{40}$ However, the "new vogue for blue" was firmly established, with master dyers specializing in blue from woad in many European towns. ${ }^{41}$

In England, woad production began later than on the Continent. According to British historian Joan Thirsk, enterprising agriculturalists began experimenting with woad in the mid-sixteenth century. ${ }^{42}$ By 1585 , a woad census carried out by the government found that in Hampshire, one of the most successful woad regions, an astounding 1,748 acres of land were devoted to woad. ${ }^{43}$ A "powerful argument" for woad was its ability to seasonally employ large numbers of the poor. ${ }^{44}$ In 1626, " 249 men, women, and young people" were recorded as "working on 41 acres of woad at Milcote, Warwickshire" in the month of June. ${ }^{45}$ An Englishman noted in 1653, "woad is nationall in that it sets many poor on work. It is the staple and chief of the Dyers' Trade, layeth a foundation for all holding [fast] colours, and much advanceth land in the rent it doubles or more." ${ }^{46}$ By the early eighteenth century, Thirsk argues that woad "was almost a synonym" for poor relief in the "public mind.",47

The scale of woad production in England was quickly seen to have a negative impact on soil fertility and decrees limiting woad production were issued in many places. For example, fears that "vital grain supplies were threatened by the craze for woad growing" prompted Elizabeth I to restrict woad agriculture around towns. ${ }^{48}$ The quote from her 1585 edict below emphasizes the personal profit gained through woad production-it was up to "six times more profitable" than food cropping ${ }^{49}$ — while recognizing a need to respect the common weal. The decree reads:

Forasmuch as the Queenes Majestie by many meanes understandeth, and specially by complaint of great nombers of her people in counties being clothing and tillage, and sustained by foode comming of Dayries, (things necessarie to be mayntayned in her Realme...) that a late attempt of breaking up \& tilling of very fertile grounds to sowe woade, is upon a late private and inordinate gayne practiced, to the manifest griefe of her people in divers places where the same is used: And that the excessive gayne founde thereby, without regarde to the publique weale, is both likely to continue and increase this attempt, to great damage of common weale

$[\ldots]$

No manner of person..., shal directly or indirectly after the publication hereof, breake up, or cause to be broken up, any manner of grounde of what nature soever it be, for the use or purpose to sowe or plant woade in, neyther that any person doe continue any grounds already broken up for that

40 Ibid., 64.

${ }^{41}$ Ibid., 66.

42 Joan Thirsk, Alternative Agriculture: A History. From the Black Death to the Present Day (Oxford: Oxford University Press, 1997), 79.

43 Ibid., 83.

44 Ibid., 89

45 Ibid., 96.

46 Walter Blith, The English Improver Improved (1653), 234. Cited in Hurry, The Woad Plant, 216.

${ }^{47}$ Thirsk, Alternative Agriculture, 89.

48 Balfour-Paul, Indigo, 38.

49 Ibid., 38. 
purpose to the use of woade, lying within foure myles of any market towne, or other towne occupying the common trade of clothing, or any citie within this Realme, or within eight miles of any house of her Majesties reserved for her accesse, upon payne [that they] shal be committed to the next common prison... ${ }^{50}$

Such bans benefited Continental woad producers, who profited from the decline of woad cultivation in England; woad was said to be the "second most popular import from France, after wine." ${ }^{1}$ In 1600, a new proclamation by Queen Elizabeth notes that "the sayd attempt of growing woade, hath rather increased then diminished" and extends the ban on ploughing new land "within this her Majesties Realme of England, or any of her Dominions, for the purpose to sowe or plant woade." 52 This clearly caused resentment in England, for the following year, Elizabeth I issued an apologetic statement nullifying all earlier restrictions on woad cultivation, excluding a three mile radius of London, any royal residences, or any other "great Citie or Towne corporate," due to the noxious smell (or "noysome savour") of woad.

Forasmuch as her Majestie had never other purpose by that restraint, then to doe that which might be for the greatest and most general benefite of her Subjects: Her Majestie is also pleased (and so she doeth) by this Proclamation set at liberty all such persons as shall thinke it for their good, to employ their grounds to the use of sowing woade... ${ }^{53}$

Hurry also notes that woad schemes came to include eight-year crop rotations, in which woad was grown for three years, after which oats and clover were planted to replenish soil fertility. ${ }^{54}$ This complex context of woad production and wealth was to shift dramatically with the entrance of indigo into Europe.

\section{Enter: Indigo}

Indigo dye first arrived on the European market in large quantities after East India Companies established trade routes to India in the seventeenth century. The arrival of indigo to Europe must be seen within a global context, for the dye was a precious but familiar commodity in the more developed south-eastern regions of the globe. In her seminal article, "Southernization," historian Lynda Shaffer uses the term southernization to refer to "a multifaceted process that began in Southern Asia and spread from there to various places around the globe." 55 "Analogous to westernization," the southernization process began with technological and material developments in regions around the Indian subcontinent and spread to other areas in the first millennium of the common era, producing "an eastern hemisphere characterized by a rich south and a north that was poor in comparison., 56

50 [Elizabeth I.] By the Queene. A proclamation against the sowing of woade. [London: Imprinted by Robert Baker. 1585.]

51 Pastoureau, Blue, 190, n25.

52 [Elizabeth I.] By the Queene. A proclamation inbibiting the sowing of woad. [London: Imprinted by Robert Baker. 1600.]

53 [Elizabeth I.] By the Queene. A proclamation for the reformation of many abuses and misdemeanours committed by patentees of certaine priviledges and licences, to the generall good of all her Majesties loving subiects. [London: Imprinted by Robert Baker. 1601.]

${ }^{54}$ Hurry, The Woad Plant, 66. See also Thirsk, Alternative Agriculture, 88 and 91.

55 Lynda Shaffer, "Southernization," Journal of World History 5, 1 (1994): 1.

56 Ibid., 1-2. 
Shaffer's article shifts the conventional Eurocentric perspective on global trade by arguing that the arrival of European merchants in the East merely expanded the booming trade routes to a new market. She posits that "the subcontinent's position in the world system was not undermined until Britain's Industrial Revolution..,57

Indigo had been a commodity within these global trade networks for centuries. Western Asia had relatively easy access to the "most prized pigments" from India, ${ }^{58}$ and indigo and cotton were exported from India as part of the "southernization of China," becoming well inscribed cultural objects in "blue-black peasant garb" during the Song dynasty (960-1279). ${ }^{59}$

Indigo, known as nil or an-nil in the Arab world, ${ }^{60}$ and indigo-dyed textiles had arrived in Europe via overland and Mediterranean routes through Islamic Spain and the Italian merchant ports since the eighth century. ${ }^{61}$ It was a vital cross-cultural commodity. In her exceptionally comprehensive book, Indigo in the Arab World, historian and dyer Jenny BalfourPaul notes that Italian late medieval paintings frequently include "depictions of blue robes...particularly those worn by the Virgin" that were embroidered with "Muslim professions of faith"'! ${ }^{62}$ The careful and detailed portrayal of such embroidered calligraphy indicates the prestige accorded to these imported textiles. According to historian Janet AbuLughod, indigo dye was among "the quintessential items of long-distance trade" due to its light weight and extremely high value. ${ }^{63}$ Hurry notes that the tropical dye reached "England in 1274" and "France in 1288." ${ }^{64}$ However, the high cost of imports meant that indigo remained an "exotic commodity like pepper, other dyestuffs and mordants, medicines and perfumes" until the sixteenth century. ${ }^{65}$ Despite this trade, the source of the dyestuff remained unclear as it "arrived from the East in the form of compact blocks," and many imagined that indigo was a "mineral in nature," even into the sixteenth century. ${ }^{66}$ A German treatise comparing woad and indigo from 1811 by F. A. von Resch narrates that

In olden times, indigo was unknown in Europe. Later, it was held to be a product of the mineral kingdom and was known by the name 'Indian stone'; even in the last century, letters patent for mining in the Principality of Halberstadt and the Earldom of Reinstein dated the $23^{\text {rd }}$ of December 1704 identifies it as one of the minerals. The permission to construct the mine was granted. As is now well known, however, indigo belongs to the plant kingdom. ${ }^{67}$

\footnotetext{
57 Ibid., 3.

58 Robert Finlay, "Weaving the Rainbow: Visions of Color in World History," Journal of World History 18, 4 (2007): 414.

${ }^{59}$ Shaffer, "Southernization," 9.

${ }^{60}$ Balfour-Paul, Indigo, 11.

${ }^{61}$ Balfour-Paul, Arab World, 17-18.

62 Balfour-Paul, Arab World, 18.

63 Janet Abu-Lughod, Before European Hegemony: The World System, A.D. 1250-1350 (New York: Oxford University Press, 1989), 68-69.

${ }^{64}$ Hurry, The Woad Plant, 257, n1.

${ }^{65}$ Balfour-Paul, Indigo, 27.

${ }^{66}$ Pastoureau, Blue, 18.

${ }^{67}$ Franz Anton von Resch, Der ausländische Indig und das Surrogat desselben, der W aid-Indig. Ein Beitrag zur Beförderung einheimischer Production (Weimar, 1811), 5. My translation. See appendix 2 for original title page.

„In den älten Zeiten kannte man den Indig in Europa nicht. Nachher hielt man ihn für ein Product des Mineralreichs und er führte den Namen des indianischen Steins; ja sogar im letzt-verflossenen Jahrhunderte
} 
Indigo imported into Europe was first employed by artists and miniature painters. ${ }^{68}$ Later, it was added to woad "in small proportions" to brighten and expand the range of possible blues. ${ }^{69}$ Following Vasco de Gama's 1498 voyage around the Cape of Good Hope, the price of indigo swiftly became more affordable to European dyers. By the early 1600s, the predominance of Portuguese merchants was challenged by the Dutch and English East India Companies, all of whom imported both indigo dye and Indian dyed textiles with their "colourfast and brilliant colours." Shipping imports into the Netherlands and England contained massive amounts of indigo. One source notes that in the year 1631, seven ships returned to Holland from India, carrying between them " 333,545 pounds" of indigo worth approximately "five tons of gold or 500,000 thalers." 71

In his book, The Industrious Revolution, Jan de Vries explores why imported commodities, such as indigo, became popular in Europe. He argues that the "elastic European demand for tropical products" was not "self-explainable" or merely due to the inherent desirability of the imported items. He suggest rather, that "new goods must be 'recognizable' to the consumer and, hence, combinable with other elements of consumption practices in order to become widely and continually consumed." "Colonial groceries" like sugar, tea, coffee, and cocoa gradually become 'recognizable' as new cultural practices developed around them. ${ }^{73}$ As we have seen, the demand for the colour blue rose sharply in the late medieval period and was originally filled by the woad producers of Europe. Indigo paralleled woad as a source of blue dye and challenged the native dyestuff as a second commodity that filled the same market.

The "colouring matter, indigotin," is identical in indigo and woad, and both dyes are processed in very similar ways. ${ }^{74}$ In contrast with other dyes such as madder or weld, neither indigo nor woad requires a mordant or hot water, and can be applied equally well to fibres of protein (such as wool and silk) or cellulose (such as cotton). ${ }^{75}$ The blues produced are also the most colourfast of natural dyes and are chemically indistinguishable from each other after dyeing. Balfour-Paul offers a succinct description of the "universal" "chemical principles" of these vat dyes:

The blue indigotin (i.e. insoluble blue dyestuff) has to be chemically reversed to its soluble leuco-form in an alkaline solution. When fibres enter an indigo vat, this colourless leuco-derivative, sometimes referred to as 'indigo white', is deposited on their surface; the blue colour does not appear until

noch wurde er in einem Freiheitsbreife für die Bergwerke in den Fürstenthume Halberstadt und der Graffschaft Reinstein vom 23. December 1704 under die Mineralien gerechnet, und den Gewerken, darauf zu bauen, verstattet. Es gehört aber solcher, wie nunmehr allgemein bekannt ist, zum Gewächsreiche."

${ }^{68}$ Hurry, The Woad Plant, 257.

${ }^{69}$ Hurry, The Woad Plant, 258; Balfour-Paul, Arab World, 31.

70 Balfour-Paul, Indigo, 44-48.

${ }^{71}$ Resch, Der ausländische Indig, 6. My translation. See appendix 2 for original title page.

„Das die Einfuhr damals schon sehr groß gewesen sein mag, erhellt daraus, daß im Jahre 1631 auf sieben, aus Indien in Holland angekommenen Schiffen sich 333,545 Pfund befanden, deren Werth zu fünf Tonnen Goldes oder 500,000 Thalern gering angeschlagen wurde.“

72 Jan De Vries, The Industrious Revolution: Consumer Behaviour and the Housebold Economy, 1650 to the Present (New York: Cambridge University Press, 2008), 155.

73 Ibid., 157.

74 Balfour-Paul, Arab World, 270.

75 Pastoureau, Blue, 74; 125. 
subsequent exposure to the air, when oxygen reconverts the dye back to its blue form. ${ }^{76}$

Ingredients such as urine, ashes, and lime were used to establish the chemical reduction in the vat. ${ }^{77}$ Despite these common characteristics, European woad dyers needed to learn how to use the new dyestuff. Hurry narrates that "in 1643, the king of Portugal sent Pero Vaz Devora to England in order to demonstrate the value of a dye called 'aneel', commonly called in English "blue ynde." London dyers experimented with this indigo and "certified that 40s. of aneel yielded as much colour as 50s. of woade and gave a more oryent (i.e. brilliant) colour." 78

\section{The Battle for the Blue Market}

However, as historian Beverly Lemire argues, "all imported goods carried political baggage." ${ }^{79}$ Just as Indian cotton imports into seventeenth century England threatened wool producers and sparked "explosive" anti-calico riots, other imports like indigo undermined local manufactures. ${ }^{80}$ Like wool, woad was also "autochthonous," arising "from local soil and entwined in its culture and economy." ${ }^{81}$ The prosperity of woad producing regions had transformed them into the "pays de cocagne" (lands of the woad ball' or more loosely translated by Pastoureau as "lands of milk and honey" "), which came to signify "exceptionally profitable land anywhere." 83 While European merchants vied for predominance in the market of "exotic commodities," the woad industry launched a powerful attack against imported blue dyes. ${ }^{84}$

In a move reminiscent of madder dyers protesting the rise of fashionable blue in the thirteenth century, woad merchants of Germany called indigo "Teufelsfarbe" (devil's dye) on the grounds that it was "an injurious, deceptive, corrosive and diabolical article." ${ }^{\text {" Indigo }}$ was banned on pain of death by the Holy Roman Emperor in 1607 and again by the Elector of Saxony in $1650 .{ }^{86}$ Resch notes that, following this example,

Duke Ernst the Pious, through his envoy Doctor Hönnen, petitioned the imperial assembly in 1652 that indigo be abolished across the Holy Roman Empire to the privilege and benefit of the honest woad dye. On the $21^{\text {st }}$ of April 1654, an imperial ban was issued, stating that the insidious entry [Einschleichung] of indigo into the realm was damaging the woad trade to the ruin of the commodity and pulling wealth out of the land. The ban ordered the prevention of indigo with all gravity and seriousness. ${ }^{87}$

\footnotetext{
${ }^{76}$ Balfour-Paul, Arab World, 84.

77 Ibid.

${ }^{78}$ Hurry, The Woad Plant, 64 n.3.

${ }^{79}$ Beverly Lemire, Cotton (New York: Berg Publishers, 2011), 47.

${ }^{80}$ Ibid.

81 Ibid., 37.

82 Pastoureau, Blue, 125.

${ }^{83}$ Balfour-Paul, Indigo, 34.

84 Balfour-Paul, Indigo, 55; Arab World, 85.

85 Pastoureau, Blue, 130; Hurry, The Woad Plant, 268.

${ }^{86}$ Hurry, The Woad Plant, 268; Balfour-Paul, Indigo, 56.

${ }^{87}$ Resch, Der ausländische Indig, 6-7. My translation. See appendix 2 for original title page.
} 
In Nuremberg, dyers were threatened with the death penalty if they failed to fulfill a legal obligation to annually renew an oath not to use indigo. ${ }^{88}$ Similarly in France, imports of indigo were prohibited in 1598, due to the "urgent representations" against it by the woad producers of Languedoc. ${ }^{89}$ Repeated royal injunctions in 1609, 1624, and 1642 banned the use of "the deceitful and injurious dye called inde" on the pain of death. ${ }^{90}$ In England as well, indigo was declared to be a "poisonous" and "dangerous drug," described as the "food for the devil." ${ }^{91}$ Use of indigo dye was forbidden by law in England from 1581 to $1660 .{ }^{92}$

Two other "competitors," logwood and Brazilwood, although considerably less potent or fast, were also used as blue dyes, and the campaign against indigo was extended to them as well. ${ }^{93}$ In 1581, Elizabeth I issued a statute prohibiting the use of logwood, due to the fact that "the colours made with the said stuff" were "false and deceitful," causing "great discredit and slander" of the merchants and dyers of England. "In 1621, the Dyers' Company of London issued a bill authorizing "Searchers...sworne before the Lord Major and Aldermen in London" to confiscate and burn all logwood. Any dyer found to be in possession of the dyestuff was to be fined the grand sum of 40 pounds, "besides such corporall punishment as by the Statute of 39. Eliz. is to be inflicted on such as use Logwood in dying, viz. To bee set on the Pillory all the market time, for one or more dayes." 95

However, this negative press was not the only response to the arrival of indigo. In 1640, English botanist John Parkinson published his encyclopedic Theatrum botanicum: The Theatre of Plants, in which he called for greater recognition of the benefits of indigo:

Although Nil or Indico be not in forme like Woade, yet for the rich blew colour sake I think it good to make mention of it here with it, not onely to shew you what it is, and how made, but to incite some of our nation, to be as industrious therein as they have beene with the former Woade, feeling no doubt but it would bee more profitable. ${ }^{96}$

„Als nun bald darauf der Indig allgemein ward, und dem absaße des Waids schadete, so verbot zuerst Chursachsen im Jahre 1650 denselben. Diesem Beispiele folgte Herzog Ernst, der fromme, der sogar im Jahre 1652 bei der Reichsversammlung durch seinen Gesandten, Doctor Hönnen, darauf antragen ließ, daß der Indig im ganzen Römischen Reiche abgeschafft, und dagegen die aufrichtige Waidfarbe priviligiert werden möchte. Unterm 21. April 1654 erfolgte auch wirklich das Kaiserliche Verbot, daß die Einschleichung des Indigs, der dem Waidhandel schade, die Waare verdürbe, und Geld aus dem Lande zöge, ernstlich verhütet werden soll.“

${ }^{88}$ Resch, Der ausländische Indig, 7; Hurry, The Woad Plant, 268; Balfour-Paul, Indigo, 57.

${ }^{89}$ Hurry, The Woad Plant, 267.

${ }^{90}$ Hurry, The Woad Plant, 267; Balfour-Paul, Indigo, 56; Pastoureau, Blue, 128.

91 Balfour-Paul, Indigo, 57; Hurry, The Woad Plant, 259.

92 Balfour-Paul, Indigo, 57.

93 Hurry, The Woad Plant, 258.

${ }^{94}$ Statute 23 Eliz., c. 9, Logwood and Blockwood shall not be used in dying of cloth, etc. Cited in Hurry, The Woad Plant, 259-263.

95 Dyers' Company (London, England). The briefe contents of the bill exhibited against logwood, and abuses in dying (sic). 1621.

96 John Parkinson, Theatrum botanicum: The Theater of Plants. Or, An herball of a large extent (England, 1640), 600601. 
Hurry suggests that even while the protectionist laws were in effect, "indigo could be purchased" in the heart of Thuringia "without police interference." "more than twenty firms" sold indigo in Leipzig, and even in Erfurt, "woad merchants themselves" were dealing in indigo. "Similarly, indigo "permeated France," completely undermining the woad industry. ${ }^{99}$ In the face of continued imports and a weakened woad lobby, indigo was finally legalized across France and Germany in $1737 .{ }^{100}$

Balfour-Paul suggests that one reason for the slander against indigo was an Indian dye method that used a highly corrosive arsenic as a reducing agent, which damaged cloth fibres. ${ }^{101}$ Confusion of indigo and the less colourfast logwood also contributed to the distrust of the new dye. However, the violent terms used against indigo indicate the presence of multiple discourses about the colour blue. Blues from woad and indigo are virtually indistinguishable after dyeing, but one was characterized as "pernicious" and "deceitful"102 while the other was "honest" and "sincere" (aufricbtig). ${ }^{103}$ In the imperial decree from the Holy Roman Emperor quoted above, the arrival of indigo in Germany is described as an insidious, creeping threat (Einschleichung), giving direct agency to the dye rather than merchant importers. These negative qualities were seen to be inherent in the dyestuff itself and in an almost magical sense, reflected on the dyers and merchants who dealt with the colour.

The gradual but ultimate failure of the protectionist measures is a testament to the strength of the import trade in reducing costs as well as the ability of European dyers to recognize "the superiority of indigo" as a dyestuff. ${ }^{104}$ Some viewed the downfall of woad as a sign of "divine retribution" for the prosperity enjoyed by the woad industry. D. G. Scherber, in his 1752 Description of Woad says, "God in His great mercy and love for mankind has decreed the temporary loss of woad, so as to bring man back to himself and a state of true happiness." Schreber further quotes a resigned statesman: "Even the wisest regulations have failed to save this jewel of Thuringia. When God for His own reasons wishes to withdraw the blessing that $\mathrm{He}$ has lent to a country for a time, we can do nothing but submit."105 According to Balfour-Paul, by the eighteenth century, European dyers had mastered indigo dye processes, with over thirteen standard separate shades of indigo in common use. ${ }^{106}$ In an ironic reversal of positions from the fifteenth century, woad was now employed as a fermenting agent in indigo vats. ${ }^{107}$ Although woad dyestuff continued to be grown agriculturally in Europe into the twentieth century, its heyday had long since passed. ${ }^{108}$

Most basically, the higher concentrations of blue pigment in indigo were the downfall of woad. However, the discursive agency accorded to indigo and woad is indicative of an ambivalence about the impact of imports on local industry. The home-grown and familiar

\footnotetext{
${ }^{97}$ Hurry, The Woad Plant, 273.

${ }^{98}$ Ibid.

99 Pastoureau, Blue, 128.

100 Ibid.

101 Balfour-Paul, Arab World, 85.

102 Balfour-Paul, Indigo, 56.

${ }^{103}$ Resch, Der ausländische Indig, 7, my translation.

104 Balfour-Paul, Indigo, 57.

105 D. G. Schreber, Beschreibung des Waidtes, 134. Cited in Hurry, The Woad Plant, 292.

106 Balfour-Paul, Indigo, 178.

107 Thirsk, Alternative Agriculture, 88.

108 Hurry, The Woad Plant, 294; Thirsk, Alternative Agriculture, 95.
} 
nature of woad, together with the massive amounts of wealth it created since the late medieval period, turned the "woad war" into a polarizing question of allegiance. ${ }^{109}$ Indigo unsettled traditional patterns of wealth circulation by drawing money out of regional areas and gradually undermined the position of woad merchants. However, it is important to remember that indigo's success was also due to its filial similarity to woad, which allowed it to be 'recognizable' and fill the same blue niche.

109 Balfour-Paul, Indigo, 55. 


\section{Bibliography}

Abu-Lughod, Janet. Before European Hegemony: The World System, A.D. 1250-1350. New York: Oxford University Press. 1989.

Balfour-Paul, Jenny. Indigo. London: Archetype Publications Ltd. 2006.

. Indigo in the Arab World. Richmond, Surry: Curzon Press. 1997.

De Vries, Jan. The Industrious Revolution: Consumer Behaviour and the Household Economy, 1650 to the Present. New York: Cambridge University Press. 2008.

Dyers' Company (London, England). The briefe contents of the bill exbibited against logwood, and abuses in dying. 1621. Accessed Dec. 12, 2011 via Early English Books Online.

http://gateway.proquest.com.login.ezproxy.library.ualberta.ca/openurl?ctx_ver=Z39.882003\&res_id=xri:eebo\&rft_id=xri:eebo:image: 28173

[Elizabeth I.] By the Queene. A proclamation against the sowing of woade. [London: Imprinted by Robert Baker. 1585.] Accessed Dec. 12, 2011 via Early English Books Online.

http://gateway.proquest.com.login.ezproxy.library.ualberta.ca/openurl?ctx_ver=Z39.882003\&res_id=xri:eebo\&rft_id=xri:eebo:image: 15795

[Elizabeth I.] By the Queene. A proclamation inbibiting the sowing of woad. [London: Imprinted by Robert Baker. 1600.] Accessed Dec. 12, 2011 via Early English Books Online.

http://gateway.proquest.com.login.ezproxy.library.ualberta.ca/openurl?ctx_ver=Z39.88-

2003\&res_id=xri:eebo\&rft_id=xri:eebo:image: 22640

[Elizabeth I.] By the Queene. A proclamation for the reformation of many abuses and misdemeanours committed by patentees of certaine priviledges and licences, to the generall good of all her Majesties loving subiects.

[London: Imprinted by Robert Baker. 1601.] Accessed Dec. 12, 2011 via Early English

Books Online.

http://gateway.proquest.com.login.ezproxy.library.ualberta.ca/openurl?ctx_ver=Z39.88-

2003\&res_id=xri:eebo\&rft_id=xri:eebo:image: 17724

Finlay, Robert. "Weaving the Rainbow: Visions of Color in World History." Journal of World History 18, 4 (2007): 383-431.

Hunt, Margaret. The Middling Sort: Commerce, Gender, and the Family in England, 1680-1780. Berkeley: University of California Press. 1996.

Hurry, Jamieson B. The Woad Plant and its Dye. London: Oxford University Press. 1930.

Lemire, Beverly. Cotton. New York: Berg Publishers. 2011.

Parkinson, John. Theatrum botanicum. The Theater of Plants. Or, An herball of a large extent. England, 1640. Accessed Dec. 12, 2011 via Early English Books Online. http://gateway.proquest.com.login.ezproxy.library.ualberta.ca/openurl?ctx_ver=Z39.88-

2003\&res_id=xri:eebo\&rft_id=xri:eebo:image:22703:310

Pastoureau, Michel. Blue: the history of a color. Princeton, NJ: Princeton University Press. 2001.

Shaffer, Lynda. "Southernization." Journal of World History 5, 1 (1994): 1-21.

Resch, Fr. Ant. von (Franz Anton). Der ausländische Indig und das Surrogat desselben, der Waid-Indig. Ein Beitrag zur Beförderung einheimischer Production. Weimar, 1811.

Accessed Dec. 12, 2011 via The Making Of The Modern World online database. http:// find.galegroup.com.login.ezproxy.library.ualberta.ca/ $\mathrm{mome} /$ infomark.do?\&source $=\mathrm{g}$ ale\&prodId=MOME\&userGroupName $=$ edmo69826\&tabID $=$ T001\&docId $=$ U110282979\& type $=$ multipage \&contentSet $=$ MOMEArticles\&version=1.0\&docLevel=FASCIMILE 
Thirsk, Joan. Alternative Agriculture: A History. From the Black Death to the Present Day. Oxford: Oxford University Press. 1997. 


\section{Appendix 1}

Map reproduced from Hurry, The Woad Plant and its Dye (1930), facing 102. A similar map can be found in Balfour-Paul, Indigo (2006), 32.

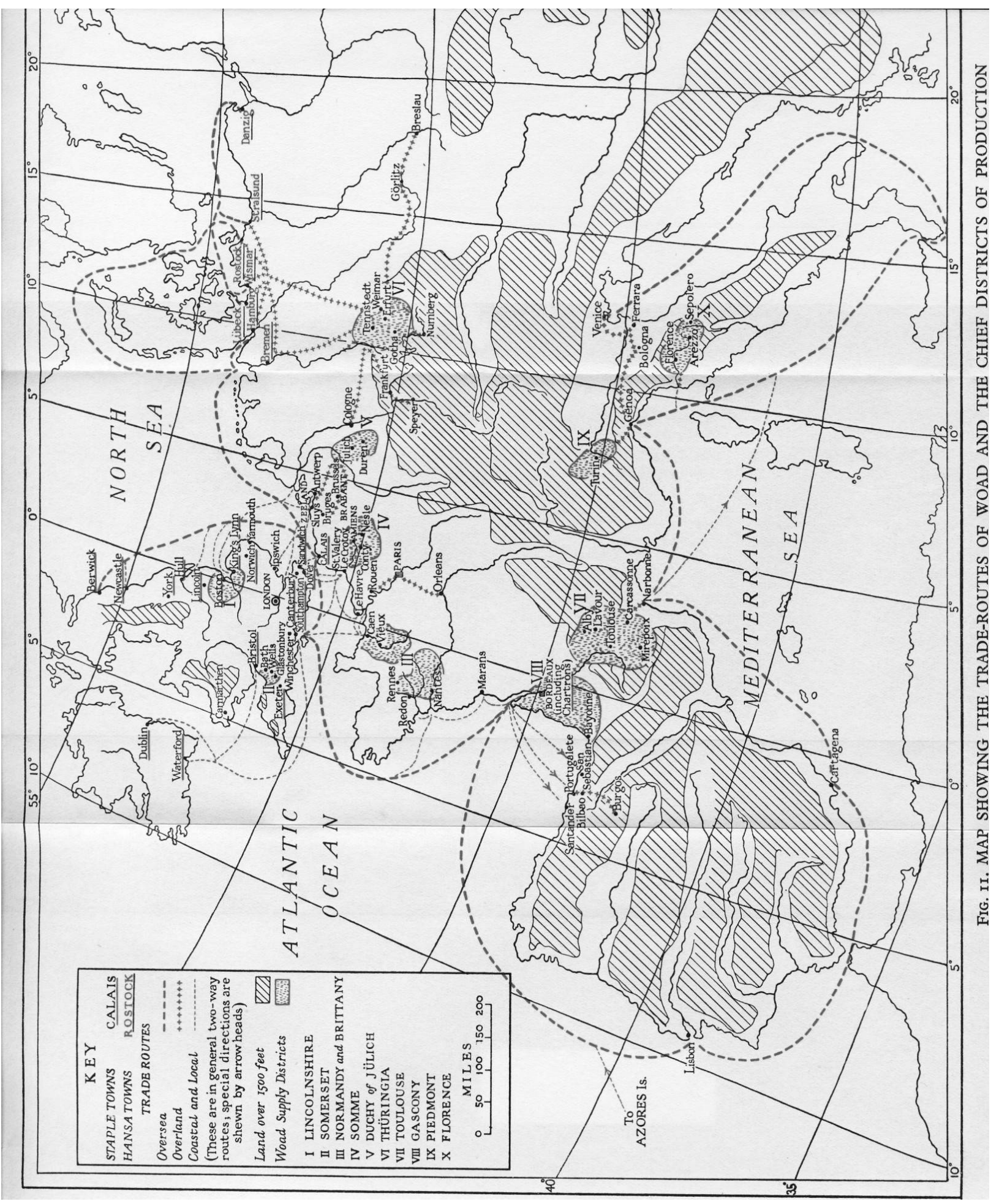




\section{Appendix 2}

Title page of Resch, Franz Anton von. Der ausländische Indig und das Surrogat desselben, der Waid-Indig. Ein Beitrag zur Beförderung einheimischer Production. Weimar, 1811.

\section{D $\mathfrak{e}$}

\section{$\mathfrak{a} \mathfrak{u} \mathfrak{i} \mathfrak{a} \mathfrak{d} \mathfrak{i} \mathfrak{d} \mathfrak{d} \mathfrak{e}$ Ind $\mathfrak{i} \mathfrak{g}$}

un

bas Surrogat beffelben,

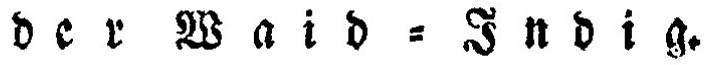

Ein Beitrag

jut Beforoerung eingeimifder Probuction

$$
\text { o o }
$$

Frt. 2 nt. von $\Re \mathfrak{e}\{d$,

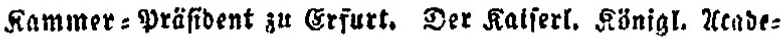

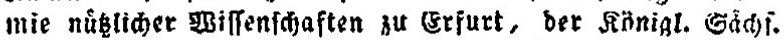

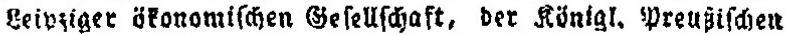

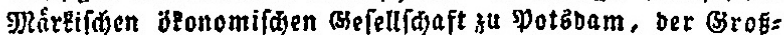
Verioglid Frankfurtion, Wetternufden Befellfaft ju 5anau, ber naturforfdienden (Selell(d)aft weftphalenz, ber

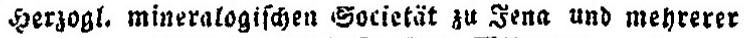
getebrten Bifellihaften gitgliebe.

WB $\mathrm{i}$ mar,

III Berlabe oez Eanoez= కnouftre= Eombtoir:

I 8 I.

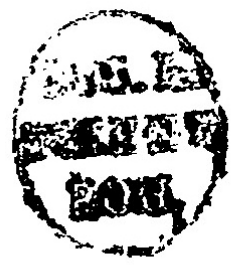

